\title{
49. GEOTECHNICAL PROPERTIES OF LAU BASIN SEDIMENTS FROM A MICROFABRIC PERSPECTIVE ${ }^{1}$
}

\author{
Kathleen M. Fischer ${ }^{2}$ and Dawn L. Lavoie ${ }^{2}$
}

\begin{abstract}
Distribution of pore space and degree of cementation appear to be the main factors controlling the permeability of sediments retrieved from the Lau Basin. The undisturbed microfabrics of two lithologies, nannofossil ooze and vitric sandy silt, commonly found at Holes $834 \mathrm{~A}, 835 \mathrm{~A}, 838 \mathrm{~A}$, and $839 \mathrm{~A}$ of Leg 135 were examined by scanning electron microscopy equipped with energy dispersive X-ray spectral analysis and image analysis systems. The results of these analyses were compared with laboratory determinations of porosity, grain-size distribution, and permeability on discrete samples from the same sediment depths. The permeability of the vitric sandy silt is 3-5 orders of magnitude higher than the nannofossil ooze samples. The porosity of nannofossil ooze ranges from $6 \%$ to $12 \%$ greater than the porosity of vitric sandy silt, which partially reflects the finer texture of nannofossil ooze. Although the correlation of higher porosity with lower permeability is not surprising, factors other than simply grain-size distribution must be invoked to explain the large differences in permeability found in these samples.
\end{abstract}

\section{INTRODUCTION}

The purpose of this study is to use high magnification examination of undisturbed sediment structure, called microfabric analysis, as a tool for understanding the large differences in permeability of the two most common sediment lithologies found at Holes $834 \mathrm{~A}, 835 \mathrm{~A}, 838 \mathrm{~A}$, and 839A in the Lau Basin during Ocean Drilling Program (ODP) Leg 135. The permeability, or permeability coefficient, is a measure of the ability of a sediment to transmit a particular fluid in the presence of a pressure, elevation, or velocity gradient and, as such, is an important property of marine sediments (Domenico and Schwartz, 1990). The permeability of a sediment controls the rate of consolidation of sediments in response to overburden pressure by controlling the rate at which pore fluids can be removed (Lambe, 1951). In certain environments, such as near-spreading centers where hydrothermal circulation occurs, sediment permeability controls advective fluid flow rates and, thereby, the transfer of heat and dissolved chemical species between the underlying upper crust and overlying seawater (Fisher et al., 1990; Mottl, 1989).

The microfabric of a sediment refers to the microscopic geometry and relationships of all the components of a sediment including primary sediment particles, diagenetic features, and pore spaces (Bennett, O'Brien, et al., 1991; Rezak and Lavoie, 1993). The spatial distribution of solid particles defines the pore-space distribution within a sediment. The microfabric of a sediment typically evolves with time and depth of burial because of the effects of various natural processes, including physical consolidation and chemical diagenesis. The primary objective of this study is to provide insight into the relationship between sediment microfabric and permeability. With respect to permeability, the most important microfabric characteristics of a sediment are the number and size of the pores and pore throats. Pores are relatively large nodes in a three-dimensional network mutually connected by throats. A pore throat is the constriction of minimal cross-sectional area of a conduit connecting one pore to another (Etris et al., 1988). The secondary objective of the present study is to elucidate the impact of various natural processes on the evolution of sediment microfabric at the Lau Basin sites.

The validity of microfabric studies relies on the preparation of a sediment sample with minimal disturbance of the natural structure. Sample preparatory techniques developed by biologists for electron

\footnotetext{
'Hawkins, J.. Parson, L.. Allan, J., et al., 1994. Proc. ODP, Sci. Results, 135: College Station, TX (Ocean Drilling Program).

${ }^{2}$ Marine Geosciences Division. Naval Research Laboratory, Stennis Space Center. MS 39529-5004. U.S.A.
}

microscopic studies of cells and tissues (Hayat, 1986) have been adapted to the preparation of marine sediment samples, particularly clays (Bowles, 1968: Bennett et al., 1977). Clays were initially studied because of the ease with which they were cut into less than $1000 \AA$ sections for high magnification examination using the transmission electron microscope (TEM). These techniques have been applied successfully to the study of the microfabric of clays from a variety of depositional environments (Bennett, Bryant, et al., 1991). Recently, techniques suitable for coarse-grained sediments, which generally cannot be sectioned for TEM examination, have been developed to study the microfabric of silts and sands (Reynolds and Gorsline, 1991). A polished surface perpendicular to bedding in a resin-embedded sample is examined. A coarse-grained sediment typically requires that a large area be examined over a wide range of magnifications to characterize the microfabric adequately. Consequently, the scanning electron microscope (SEM) is most often used for sands and silts.

Sites $834,835,838$, and 839 were located between the Lau Ridge and the Central and Eastern Lau spreading centers (Fig. 1). Holes 834A and $835 \mathrm{~A}$ were drilled in separate sub-basins $48 \mathrm{~km}$ apart, whereas Holes $838 \mathrm{~A}$ and $839 \mathrm{~A}$ were located within the same sub-basin but separated by a low ridge of $400-600 \mathrm{~km}$ relief. Although several samples were studied from the different lithologies at the four sites, five representative samples were selected for reporting here (Table 1). Four samples were taken from depths that ranged from $\sim 67$ to $80 \mathrm{mbsf}$ (approximately $325-400 \mathrm{kPa}$ of overburden pressure) within the sediment column at the four holes. It was not possible to obtain samples at identical depths; however, these four samples are considered approximately equivalent with respect to burial overburden pressure. Results for a fifth sample taken at 32.45 mbsf (approximately $155 \mathrm{kPa}$ of overburden pressure) in Hole $834 \mathrm{~A}$ are also reported for comparison of microfabric effects caused by overburden pressure.

\section{METHODS}

The samples selected for microfabric study, and brief lithologic and physical properties descriptions, are listed in Table 1. Geotechnical measurement procedures and results are described more fully in the Initial Reports volume (Parson, Hawkins, Allan, et al., 1992, pp. 49-79) and in Lavoie et al. (this volume).

Preparation of samples for microfabric examination consisted of the following steps: sample trimming, dehydration (sequential fluid exchange followed by critical point drying in liquid carbon dioxide), embedding in epoxy, polishing, and carbon coating. SPURR epoxy resin (Spurr, 1969) was the embedding material. The samples were 
Table 1. Physical properties of sediments selected for microfabric analysis.

\begin{tabular}{|c|c|c|c|c|c|c|c|c|}
\hline \multirow{2}{*}{$\begin{array}{l}\text { Core, section, } \\
\text { interval }(\mathrm{cm})\end{array}$} & \multirow{2}{*}{$\begin{array}{l}\text { Recovery } \\
\text { depth } \\
\text { (mbsf) }\end{array}$} & \multirow[b]{2}{*}{ Lithology } & \multicolumn{3}{|c|}{ Percent by weight } & \multirow{2}{*}{$\begin{array}{l}\text { Testing depth } \\
\text { equivalent } \\
\text { (mbsf) }\end{array}$} & \multirow{2}{*}{$\begin{array}{c}\text { Porosity } \\
(\%)\end{array}$} & \multirow{2}{*}{$\begin{array}{l}\text { Permeability } \\
\text { coefficient } \\
(\mathrm{cm} / \mathrm{s})\end{array}$} \\
\hline & & & Sand & Silt & Clay & & & \\
\hline $135-834 \mathrm{~A}-4 \mathrm{H}-4,135-140$ & 32.45 & $\begin{array}{l}\text { Clayey nannofossil } \\
\text { ooze }\end{array}$ & 13.5 & 82.4 & 4.1 & $\begin{array}{l}37.11 \\
70.80\end{array}$ & $\begin{array}{l}73 \\
70\end{array}$ & $4.2 \times 10^{-8}$ \\
\hline $135-834 \mathrm{~A}-9 \mathrm{H}-4,135-140$ & 79.95 & $\begin{array}{l}\text { Nannofossil ooze } \\
\text { (dry, friable) }\end{array}$ & 2.3 & 92.7 & 5.0 & $\begin{array}{r}58.31 \\
118.65\end{array}$ & $\begin{array}{l}78 \\
75\end{array}$ & $<10^{-10}$ \\
\hline $135-835 \mathrm{~A}-8 \mathrm{H}-4,135-140$ & 72.35 & $\begin{array}{l}\text { Nannofossil ooze } \\
\text { (friable) }\end{array}$ & 21.0 & 74.2 & 4.8 & $\begin{array}{r}75.42 \\
145.77\end{array}$ & $\begin{array}{l}72 \\
70\end{array}$ & $\begin{array}{l}5.6 \times 10^{-7} \\
2.8 \times 10^{-7}\end{array}$ \\
\hline $135-838 \mathrm{~A}-8 \mathrm{H}-4,135-140$ & 66.55 & $\begin{array}{l}\text { Nannofossil ooze } \\
\text { with vitric sand } \\
\text { and gravel }\end{array}$ & 4.4 & 88.8 & 6.8 & $\begin{array}{r}73.81 \\
134.84\end{array}$ & $\begin{array}{l}72 \\
67\end{array}$ & $\begin{array}{l}5.1 \times 10^{-7} \\
9.5 \times 10^{-8}\end{array}$ \\
\hline $135-839 \mathrm{~A}-8 \mathrm{H}-4,135-140$ & 67.35 & $\begin{array}{l}\text { Vitric silt and } \\
\text { sand }\end{array}$ & 35.5 & 60.5 & 4.0 & $\begin{array}{r}73.82 \\
151.02\end{array}$ & $\begin{array}{l}66 \\
65\end{array}$ & $\begin{array}{l}1.5 \times 10^{-4} \\
4.0 \times 10^{-5}\end{array}$ \\
\hline
\end{tabular}

Notes: Sand $=>63 \mu \mathrm{m}$, silt $=<63 \mu \mathrm{m}$ and $>3.9 \mu \mathrm{m}$, and clay $=<3.9 \mu \mathrm{m}$. All tests were conducted in a triaxial consolidometer with effective stress applied in both horizontal and vertical directions relative to bedding.

handled at all times in such a manner as to minimize disturbance and to retain, therefore, the in-situ arrangement of particles and pores. A description of procedures followed from initial trimming through embedding can be found in Bennett et al. (1977). Embedded samples were polished using a series of alumina grits $(5.0,0.3$, and $0.05 \mu \mathrm{m})$ suspended in water.

Samples were examined with an Amray 1820 SEM typically in backscatter electron (BSE) mode at an accelerating voltage of $15 \mathrm{KeV}$. Constituent elements with atomic numbers greater than 10 were identified by energy dispersive X-ray (EDX) spectral analysis. A Kevex Analyst 8000 Image Analysis System was used to estimate several feature (i.e., particle cross-section) parameters. Electron photomicrographs were taken with Kodak black-and-white Polaroid film (ASA 50).

\section{RESULTS}

\section{Electron Micrographs and EDX Analysis}

The BSE micrographs presented in Plates $1-6$ record typical areas of the polished surfaces of the samples listed in Table 1. A uniform magnification of $200 \times$ was chosen for presentation to facilitate comparison. This magnification provides an image of an actual sample area of approximately $0.23 \mathrm{~mm}^{2}$ and permits resolution of sand- and most silt-size particles. Although not presented here, all samples were studied at $1000 \times$ or greater magnifications to examine the fine siltand clay-size fraction in greater detail. In all cases, unembedded, fractured samples were studied, as well, at high magnifications. This is particularly important for the nannofossil oozes as the supporting matrix is composed of fine silts and clays. The EDX results are discussed below along with the electron micrographs.

\section{Samples $135-834 A-4 H-4,135-140 \mathrm{~cm}$, and $-9 \mathrm{H}-4,135-140 \mathrm{~cm}$}

Sample 135-834A-4H-4, 135-140 cm, is a nannofossil ooze with numerous large floating foraminifers and broken tests (Plate 1). In contrast, Sample 135-834A-9H-4, 135-140 cm, contains very few large foraminifers (Plate 2). Generally, the silt- and sand-size particles in Sample 135-834A-9H-4, 135-140 cm, are volcanic shards, many of which showed dissolution features and alteration. It is unknown if dissolution and alteration of these particles occurred in-situ. A fractured subsample (i.e., not embedded and polished) was examined using both secondary electron (SE) and BSE modes. A thin, pervasive veneer of amorphous material was apparent when viewed using the SE mode. This veneer disappeared upon examination using the BSE mode, which originates from deeper in the sample. The EDX results for the matrix of Sample 135-834A-9H-4, 135-140 cm (Fig. 2) showed the presence of greater proportions of iron, silicon, aluminum, and potassium than were present in the nannofossil ooze matrix of Sample 135-834A-4H-4, 135-140 cm, taken uphole at approximately 32.45 mbsf (Fig. 3). (Chlorine is the only element other than carbon, hydrogen, and oxygen that can be contributed by the resin). The higher integrated count value in Figure 3 is insufficient to explain the higher proportion of these elements in Sample 135-834A-9H-4, 135$140 \mathrm{~cm}$. Further inspection of the fractured subsample (Plate 3) showed several clusters of lath-like crystals in large pores. The EDX analyses of these crystals indicated that the laths were composed of sodium, potassium, aluminum, and silicon. These semi-quantitative compositional results and the morphology of the crystals suggest that the crystal cluster is an authigenic $\mathrm{Na}, \mathrm{K}$-zeolite such as phillipsite.

\section{Sample 135-835A-8H-4, 135-140 cm}

Sand- and silt-size particles are predominantly foraminifers and foraminifer fragments, both of which show extensive dissolution features and natural breakage (Plate 4). Obvious structural differences in the walls of individual foraminifers were analyzed by EDX and, in all cases, were found to contain apparently pure calcium (as carbonate). The fine-grained matrix of this sample showed considerably reduced levels of iron, silicon, aluminum, and potassium compared with Sample 135-834A-9H-4, 135-140 cm.

\section{Sample 135-838A-8H-4, 135-140 cm}

Sand- and silt-size particles in this sample are a mixture of volcanic shards and foraminifers. Many of the foraminifers show natural breakage and dissolution features (Plate 5).

\section{Sample 135-839A-8H-4, 135-140 cm}

The grains in this sample are primarily vitric ash particles (Plate 6 ). The black areas are regions (previously pore space) filled with 


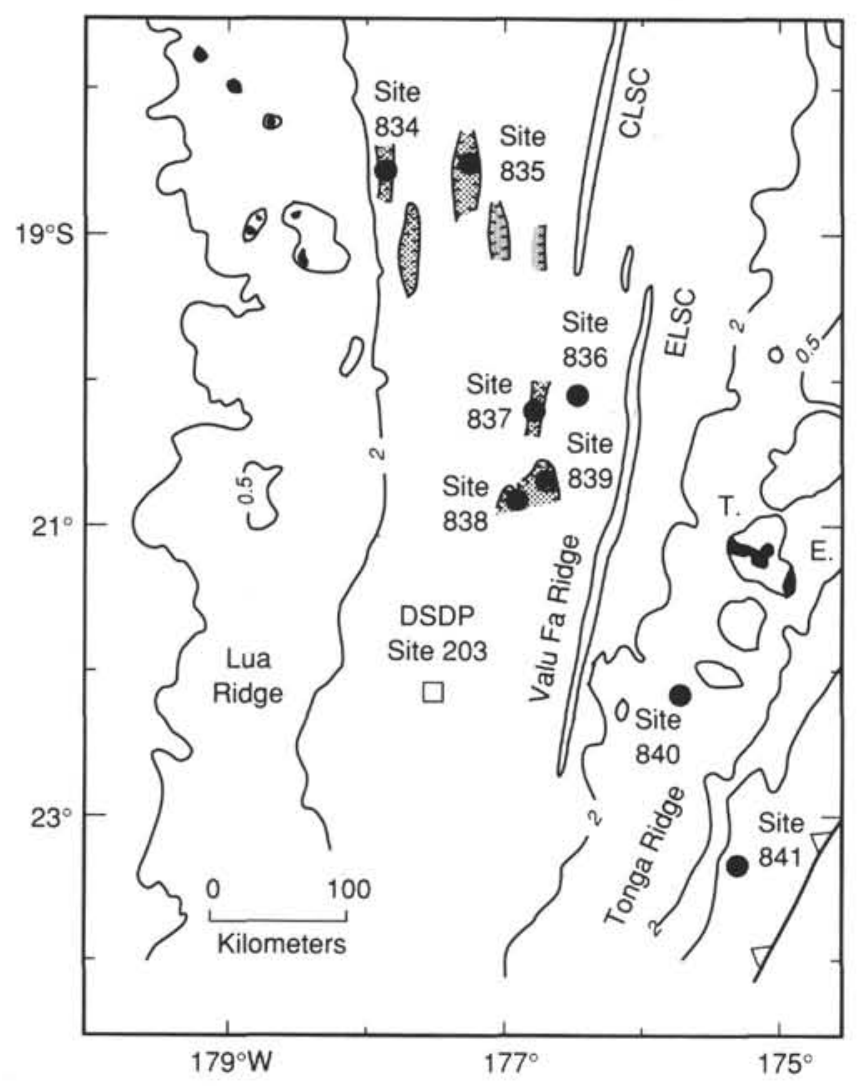

Figure 1. Map of backarc sites drilled during Leg 135 with 500 and $2000 \mathrm{~m}$ isobaths drawn. Known sub-basins are stippled. ELSC $=$ East Lau Spreading Center, CLSC $=$ Central Lau Spreading Center, $\mathrm{T}=$ Tongatapu, and $\mathrm{E}=$ 'Eua (Parson, Hawkins, Allan, et al., 1992).

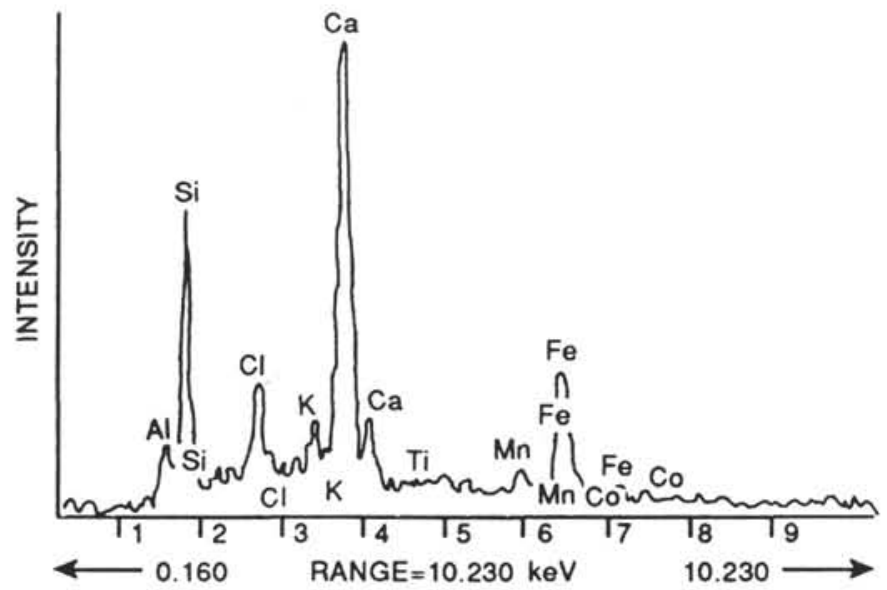

Figure 2. EDX spectra of the fine-grained matrix of Sample 135-834A-9H-4. $135-140 \mathrm{~cm}$, recovered from a sediment depth of 79.95 mbsf. Maximum vertical counts $=314$, integrated counts $=27021$, and counting interval $=60 \mathrm{~s}$.

epoxy resin. The clear distinction of resin-filled regions at this magnification provides evidence for wide, continuous pores in comparison with the previously discussed four samples. The EDX analyses of almost all particles in this sample show high silicon contents with minor amounts of aluminum, calcium, iron, potassium, and titanium (Fig. 4). Evidence of former gaseous inclusions in this vitric sandy silt is provided by remnant bubble features, most of which are clearly broken and presumably broken naturally.

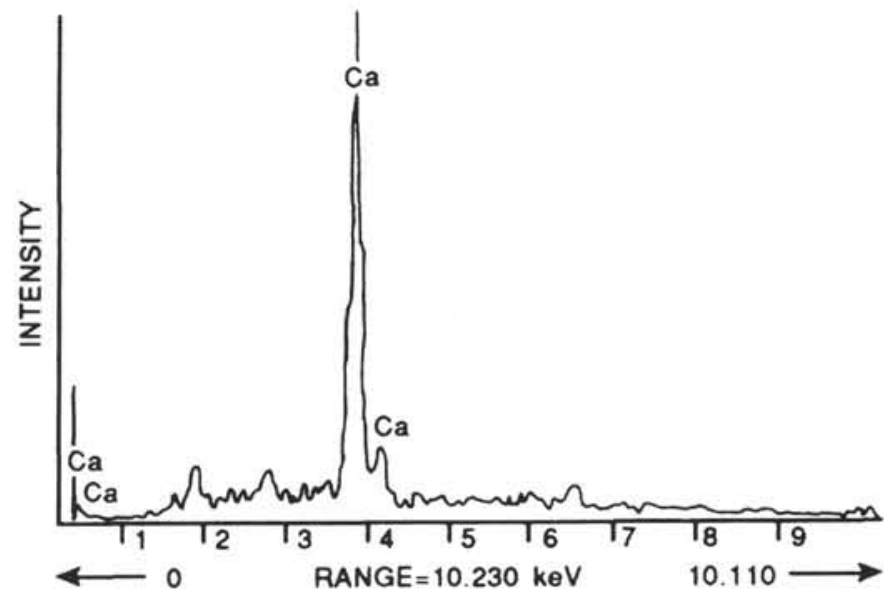

Figure 3. EDX spectra of the fine-grained matrix of Sample 135-834A-4H-4, $135-140 \mathrm{~cm}$, recovered from a depth of $32.45 \mathrm{mbsf}$. See Figure 3 for identification of unlabeled peaks. Maximum vertical counts $=416$, integrated counts $=17822$ and counting interval $=60 \mathrm{~s}$.

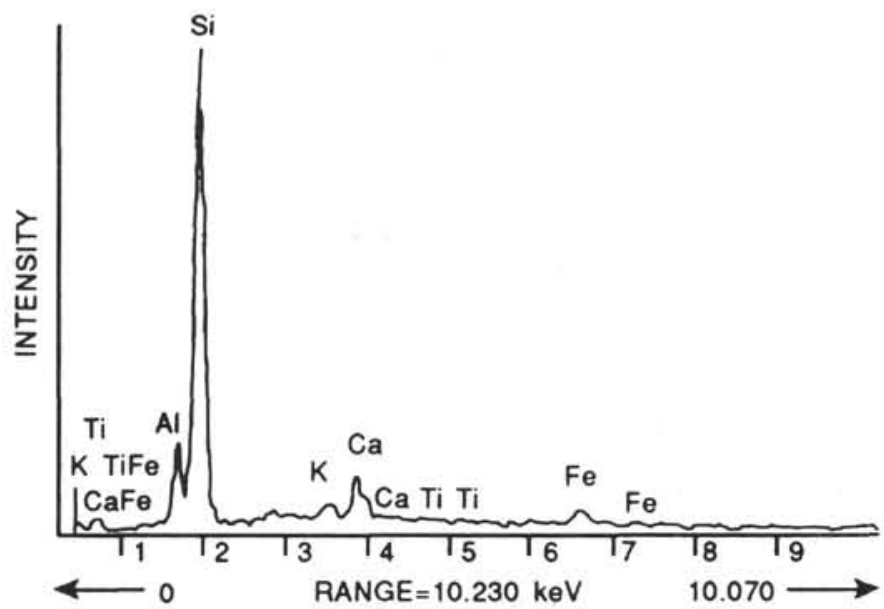

Figure 4. EDX spectra from the central portion of a vitric sand shard in Sample $135-839 \mathrm{~A}-8 \mathrm{H}-4,135-140 \mathrm{~cm}$. Maximum vertical counts $=849$, integrated counts $=29341$ and counting interval $=60 \mathrm{~s}$.

\section{Image Analysis}

The gray-level cutoff (i.e., the gray-level value that distinguished features from background) was selected by visually comparing the resulting image on the image analysis monitor with the image on the SEM monitor. In general, the resulting image for analysis was fairly insensitive to choice of gray-level cutoff, thereby reducing sample differences attributable to operator selection of gray-level cutoff. This was true for all magnifications studied $(100 \times, 200 \times$, and $1000 \times)$. The cumulative feature area, expressed as percent of field area (Table 2), is used to estimate porosity, that is, $100-$ (feature area as percentage of field = porosity. Multiple measurements at a given magnification represent analyses of different areas in the sample. Analyses at $1000 \times$ were conducted on areas without sand or coarse silts in order to sample the finer grained material. Although analysis at $1000 \times$ represented a much smaller area of the sample when compared with analysis at $200 \times$, more features were distinguished at $1000 \times$ so that sampling statistics were actually improved at the higher magnification; however, multiple areas had to be studied at $1000 \times$ to ensure a representative image analysis porosity.

The image analysis results for all fine-grained samples are presented in Table 2 . The image analysis porosity at $100 \times$ and $200 \times$ for 
Table 2. Cumulative feature area and estimated porosity from image analysis compared with porosity calculated from laboratory measurements.

\begin{tabular}{|c|c|c|c|c|}
\hline $\begin{array}{l}\text { Core, section, } \\
\text { interval }(\mathrm{cm})\end{array}$ & Magnification & $\begin{array}{l}\text { Feature area } \\
\text { ( } \% \text { of field) }\end{array}$ & $\begin{array}{c}\text { Porosity } \\
\text { estimated from } \\
\text { Image Analysis } \\
(\%)\end{array}$ & $\begin{array}{l}\text { Laboratory } \\
\text { porosity } \\
(\%)\end{array}$ \\
\hline \multirow[t]{2}{*}{$135-834 \mathrm{~A}-4 \mathrm{H}-4,135-140$} & $\begin{array}{l}200 x \\
\text { Aver }\end{array}$ & $\begin{array}{r}10.0 \\
6.8 \\
7.2 \\
13.7 \\
16.8 \\
13.2 \\
\text { rage: } 11.3\end{array}$ & 88.7 & 73 \\
\hline & $\begin{array}{l}1000 \times \\
\text { Aver }\end{array}$ & $\begin{array}{r}18.8 \\
20.4 \\
28.6 \\
23.2 \\
41.4 \\
\text { rage: } 26.5\end{array}$ & 73.5 & \\
\hline $135-834 \mathrm{~A}-9 \mathrm{H}-4,135-140$ & $\begin{array}{l}200 x \\
\text { Aver }\end{array}$ & $\begin{array}{r}14.0 \\
11.6 \\
\text { rage: } 12.8\end{array}$ & 87.2 & 78 \\
\hline \multirow[t]{2}{*}{$135-835 \mathrm{~A}-8 \mathrm{H}-4,135-140$} & ${ }^{100 x} \mathrm{Av}$ & $\begin{array}{r}4.8 \\
8.0 \\
\text { erage: } 6.4\end{array}$ & 93.6 & 72 \\
\hline & $1000 x$ & 14.9 & 85.1 & \\
\hline $135-838 \mathrm{~A}-8 \mathrm{H}-4,135-140$ & $\begin{array}{l}200 x \\
\text { Aver }\end{array}$ & $\begin{array}{r}22.0 \\
20.8 \\
\text { rage: } 21.4\end{array}$ & 78.6 & 72 \\
\hline $135-839 \mathrm{~A}-8 \mathrm{H}-4,135-140$ & $200 x$ & $\begin{array}{r}33.4 \\
28.6 \\
36.8 \\
36.1 \\
30.8 \\
27.5 \\
34.3 \\
28.5 \\
32.7 \\
30.0 \\
\text { rage: } 31.9\end{array}$ & 68.1 & \\
\hline
\end{tabular}

Notes: A magnification of $200 \times$ corresponds to an area of analysis of approximately 0.23 $\mathrm{mm}^{2}$. A magnification of $1000 \times$ corresponds to an area of analysis of approximately $9300 \mathrm{\mu m}^{2}$. Laboratory porosity is calculated from water content, average grain density, and density of interstitial water.

all nannofossil oozes was significantly higher than laboratory-determined porosity (i.e., the cumulative feature area is too low). Because the oozes have a fine-grained matrix, which is not resolvable at $200 \times$, the cumulative feature area at $1000 \times$ was determined. For Sample $135-834 \mathrm{~A}-4 \mathrm{H}-4,135-140 \mathrm{~cm}$, image analysis porosity at $1000 \times$ was $73.5 \%$ compared with a laboratory porosity of $73 \%$. When a magnification of only $200 \times$ was used, the porosity estimated by image analysis was much higher than laboratory-determined porosity $(88.7 \%$ compared to $73 \%$ ). In comparison, analysis of Sample 135-839A-8H-4, $135-140 \mathrm{~cm}$, the vitric sandy silt, at $200 \times$ provided a very good agreement between image analysis porosity $(68.1 \%)$ and laboratory porosity $(66 \%)$.

The statistical data for the area of individual features (i.e., minimum, maximum, mean, and standard deviation) provide basic characteristics of analyzed features (cross-sections of particles) for comparison of different areas in a sample or between samples. These statistics are seldom directly comparable with laboratory-determined grain size distribution; however, these statistics provide information necessary to interpret the image analysis results. These data were converted to the diameter of a circle of equal area. The results of these calculations indicate that the mean feature diameter is that of a fine silt $(7-18 \mu \mathrm{m})$ for all analyses performed at $200 \times$. Standard deviations show that the size distribution of selected features is skewed toward feature diameters greater than the mean. At $200 \times$, the minimum diameter that could be resolved was $4.4 \mu \mathrm{m}$; that is, only sands and silts could be resolved at this magnification. The boundary between silt and clay is defined as $3.9 \mu \mathrm{m}$. For analyses conducted at $1000 \times$, the mean feature diameter ranged from 2.6 to $4.3 \mu \mathrm{m}$ (i.e., clay-size particles). The standard deviation at $1000 \times$ also showed skewing toward diameters greater than the mean. The minimum feature diameter able to be resolved at this magnification is $0.87 \mu \mathrm{m}$.

\section{DISCUSSION}

Each micrograph (and the image analyses based on it) represents a cross-section through the sediment that randomly samples all pore space, including the pore throats, that conduct fluid. Within the error of laboratory and image analysis porosity estimates, all of the pore space of Sample 135-839A-8H-4, 135-140 cm, the vitric sandy silt, is clearly discernable by image analysis at a magnification of only $200 \times$, as compared to a magnification of $1000 \times$ required to resolve the porosities of the nannofossil oozes. The much higher permeability of the vitric sandy silt, then, is a result of the much larger pores and pore throats, as sampled by the micrographs. The vitric sandy silt also has a comparatively high mechanical strength, as implied by a porosity reduction of only $1 \%$ with an application of overburden pressure equivalent to an additional $\sim 80 \mathrm{~m}$ burial depth. Thus, the vitric sandy silt and similar lithologies can provide relatively stable and permeable conduits for fluid transport.

Differences in laboratory grain size distributions (Table 1) do not correlate with permeabilities in all cases. Samples 135-834A-9H-4, $135-140 \mathrm{~cm}$, and $135-838 \mathrm{~A}-8 \mathrm{H}-4,135-140 \mathrm{~cm}$, have very similar grain size distributions but differ by more than two orders of magnitude in permeability. The low permeability of Sample 135-834A-9H$4,135-140 \mathrm{~cm}$, is more convincingly explained by the presence of a cement that clogs pore throats and channels. This sample, a dry and friable nannofossil ooze, had a permeability below the range of accurate measurement with the equipment employed. An SEM examination of a fractured subsample to compare images obtained using the SE and BSE modes revealed that a fine layer of amorphous material coated and cemented constituent particles of all sizes. This cement was apparently of low average atomic number. Comparison of the EDX results of this sample with an uphole sample showed increases in the proportions of iron, silicon, aluminum, and potassium, suggesting an authigenic clay, possibly mixed with some iron oxide. Radiating clusters of crystal laths were found in large pores within this sample. The EDX analysis indicated that this authigenic, lath-shaped mineral was composed of sodium, potassium, aluminum, and silicon. Previous work (von Stackelberg and von Rad, 1990) identified clusters of similar morphology as phillipsite. Although the environmental conditions leading to the formation of a clay-like cement in this sample are unknown, it should be noted that this hole had comparatively high heat flow and the sample was taken from a layer of interbedded nannofossil oozes and volcanic silts and sands (Parson, Hawkins, Allan, et al., 1992). A continuous layer of sediment similar to this sample would act as a semi-permeable aquitard, channeling fluid flow laterally through adjacent, more permeable layers.

Sample 135-835A-8H-4, 135-140 cm, was also friable upon handling and showed extensive dissolution and natural breakage of foraminifers. Porosity decreased only $2 \%$ with application of additional stress estimated to equal an additional $70 \mathrm{~m}$ of depth below the depth of recovery, suggesting cementation. However, this sample had a permeability at least 3 orders of magnitude higher than Sample $135-834 \mathrm{~A}-9 \mathrm{H}-4,135-140 \mathrm{~cm}$. Differences in grain-size distribution as determined by standard laboratory methods (Table 1) between these two samples cannot be invoked as a reason for the differences in permeability as all the sand-size material is supported by a finegrained matrix. The EDX analysis of the matrix of this sample did not indicate the presence of substantial amounts of the same elements found in the cement in Sample 135-834A-9H-4, 135-140 cm. The matrix of Sample 135-835A-8H-4, 135-140 cm, was composed predominantly of calcium (as carbonate) with slight amounts of silicon 
and aluminum (probably clays) and iron (probably as an oxide). This suggests that the cement involved is calcium carbonate. The extent of carbonate cementation of particles in this sample may mechanically stabilize the sediment structure, but cementation has not developed sufficiently to close pore throats and reduce permeability. Downhole heat flow variations (Lavoie et al., this volume) indicate probable downwelling of seawater in this hole; the permeability of this sample suggests that fluid advection through this sediment would be reasonably efficient.

\section{CONCLUSIONS}

The samples studied have a wide range of permeabilities that do not show consistent correlation with grain-size distributions. Frequently, samples with high porosities have low permeabilities; however, grain-size distributions do not demonstrate consistently the presence of a significantly larger fraction of fine-grained material in samples of high porosity. Microfabric analysis suggests that the following two factors control the permeability of these samples: (1) distribution of pore space and (2) degree, and possibly type, of cementation. The pore space of the most permeable sample, a vitric sandy silt, apparently consists of comparatively large pore throats that are easily resolvable at $200 \times$ by image analysis. Image analysis results indicate that a magnification of at least $1000 \times$ is required to begin to predict the porosities of the nannofossil oozes accurately. The sandsize fraction of the nannofossil oozes contains a substantial intraparticle pore space that does not contribute to permeability. The sand-size particles are embedded and supported by a fine-grained (fine silt- to clay-size) matrix that controls the permeability of these samples.

The extremely low permeability of one nannofossil ooze was attributable to the presence of an amorphous, authigenic cement of clay-like composition. Formation of this cement may be the result of the comparatively high heat flow at this hole (among the four holes represented in this study) and the proximity (interbedding) of this sediment to volcanic silts and sands. Carbonate cementation in a nannofossil ooze sample from a different hole had evidently not developed sufficiently to reduce permeability significantly.

\section{ACKNOWLEDGMENTS}

Financial support for this study was provided by the Naval Research Laboratory (NRL), DOD Program Element Number 0601153N. We thank Alexander Falster, University of New Orleans, for operating the SEM and associated instrumentation employed in this study. The University of New Orleans, Department of Geology, is gratefully acknowledged for allowing us to use their instrumentation. We thank W.P. Richardson, K.D. Kennedy, and C. Farno, all of NRL, for their assistance with sample preparation. We are grateful to M.D. Richardson, NRL, and W.R. Bryant, Texas A\&M University, for their critical reviews of this manuscript.

\section{REFERENCES}

Bennett, R.H., Bryant, W.R., and Hulbert, M.H., 1991. Microstructure of FineGrained Sediments: From Mud to Shale: New York (Springer-Verlag).

Bennett, R.H., Bryant. W.R., and Keller, G.H., 1977. Clay Fabric and Geotechnical Properties of Selected Submarine Sediment Cores from the Mississippi Delta. NOAA Prof. Pap.. 9.

Bennett, R.H., O'Brien. N.R., and Hulbert, M.H., 1991. Determinants of clay and shale microfabric signatures: processes and mechanisms. In Bennett, R.H., Bryant, W.R.. and Hulbert, M.H. (Eds.), Microstructure of FineGrained Sediments: From Mud to Shale: New York (Springer-Verlag).

Bowles, F.A., 1968. Microstructure of sediments: investigation with ultra-thin sections. Science, 159:1236-1237.

Domenico, P.A., and Schwartz, F.W., 1990. Physical and Chemical Hydrogeology: New York (Wiley).

Etris, E.L., Brumfield, D.S., Ehrlich, R., and Crabtree, S.J., Jr., 1988. Relations between pores, throats and permeability: a petrographic/physical analysis of some carbonate grainstones and packstones. Carbon. Evapor., 3:17-32.

Fisher, A.T., Becker, K., Narasimhan, T.N., Langseth, M.G., and Mottl, M.J., 1990. Passive, off-axis convection through the southern flank of the Costa Rica Rift. J. Geophys. Res., 95:9343-9370.

Hayat, M.A., 1986. Basic Techniques for Transmission Electron Microscopy: Orlando. FL (Academic).

Lambe, T.W., 1951. Soil Testing for Engineers: New York (Wiley).

Mottl, M.J., 1989. Hydrothermal convection, reaction, and diffusion in sediments on the Costa Rica Rift flank: pore-water evidence from ODP Sites 677 and 678. In Becker, K., Sakai, H., et al., Proc. ODP, Sci. Results, 111: College Station, TX (Ocean Drilling Program), 195-213.

Parson, L., Hawkins, J., Allan, J., et al., 1992. Proc. ODP, Init. Repts., 135: College Station, TX (Ocean Drilling Program).

Reynolds, S., and Gorsline, D.S.. 1991. Silt microfabric of detrital, deep sea mud(stone)s (California Continental Borderland) as shown by backscattered electron microscopy. In Bennett, R.H., Bryant, W.R., and Hulbert, M.H. (Eds.), Microstructure of Fine-Grained Sediments: From Mud to Shale: New York (Springer-Verlag), 203-211.

Rezak, R., and Lavoie. D. (Eds.), 1993. Carbonate Microfabrics: Heidelberg (Springer-Verlag).

Spurr, A.R., 1969. Alow-viscosity epoxy resin embedding medium for electron microscopy. J. Ultrastruct. Mol. Struct. Res., 26:31-43.

von Stackelberg, U., and von Rad, U., 1990. Geological Evolution and Hydrothermal Activity in the Lau and North Fiji Basins (Southwest Pacific Ocean, SONNE Cruise SO-35): Hannover (Alfred-Bentz-Haus).

\footnotetext{
Abbreviations for names of organizations and publication titles in ODP reference lists follow the style given in Chemical Abstracts Service Source Index (published by American Chemical Society).
}

Date of initial receipt: 30 June 1992

Date of acceptance: 11 August 1993

Ms 135SR-147 


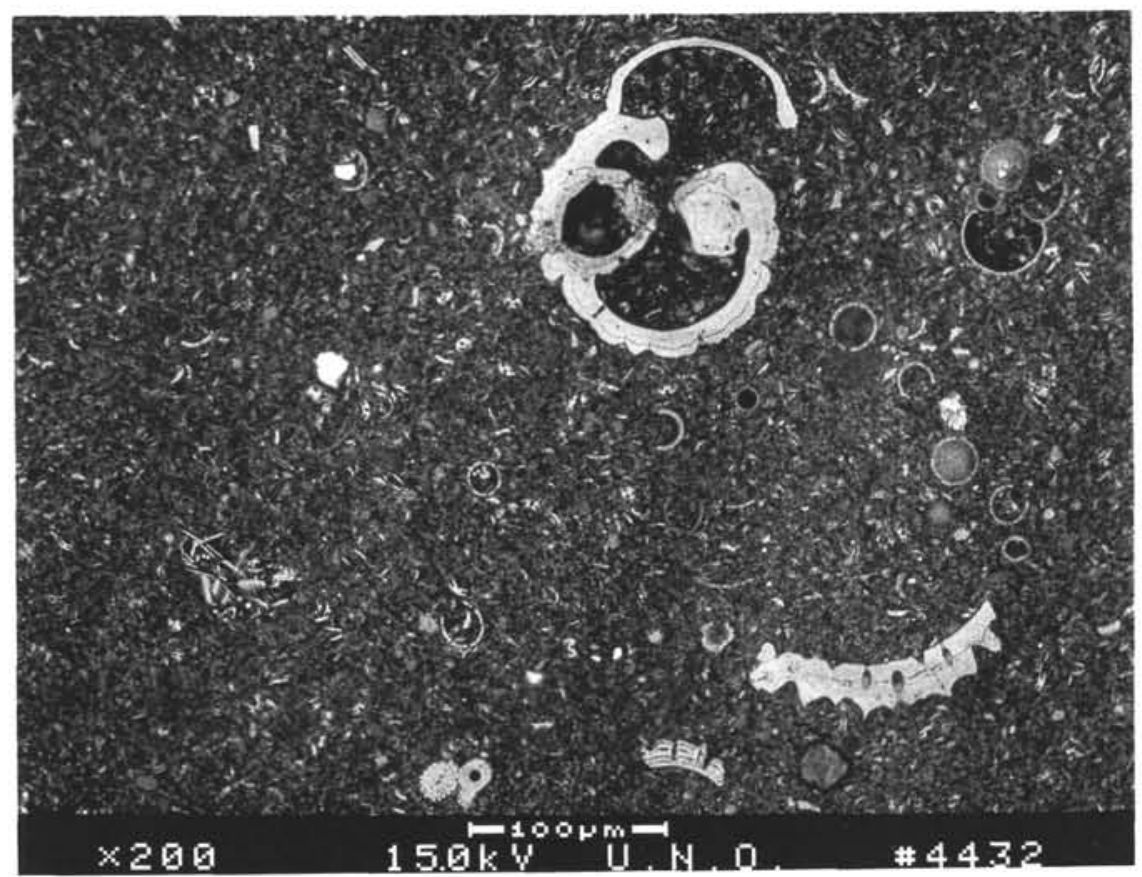

Plate 1. BSE micrograph of Sample 135-834A-4H-4, 135-140 cm.

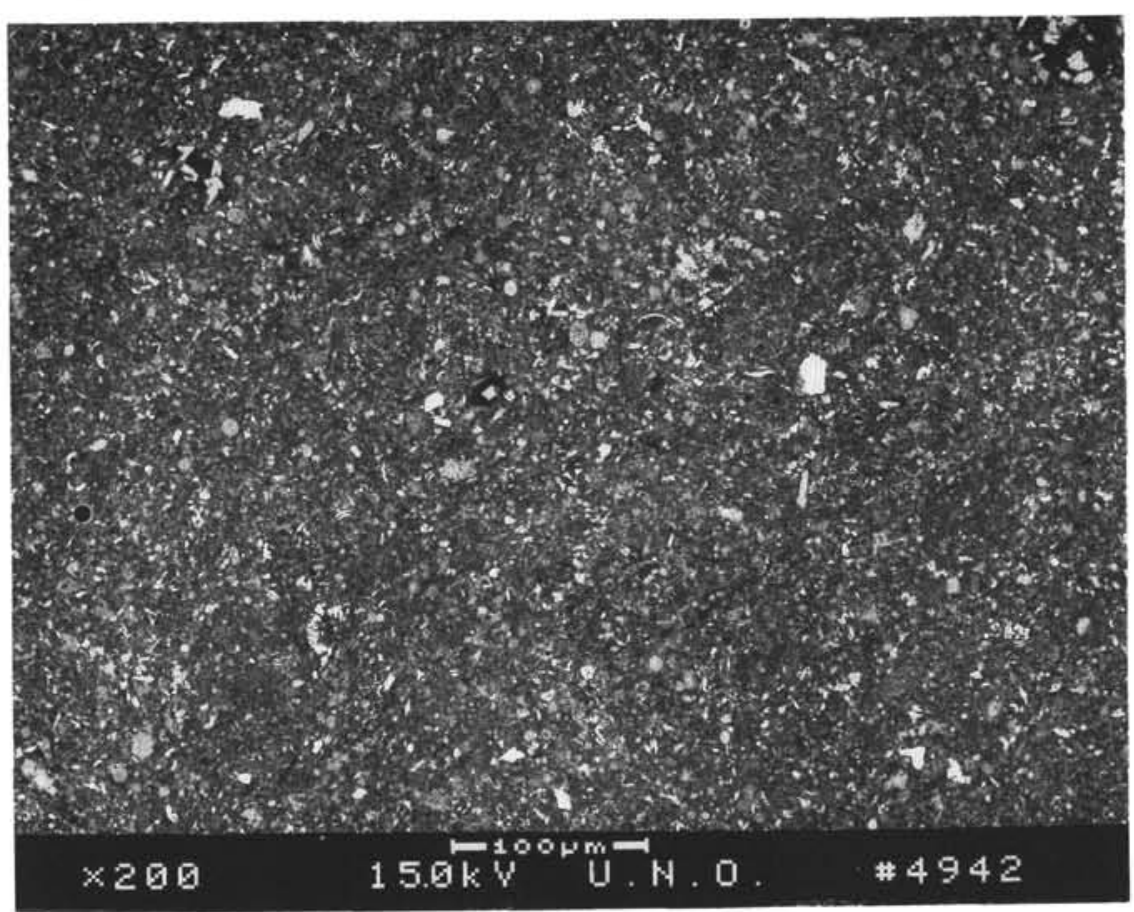

Plate 2. BSE micrograph of Sample 135-834A-9H-4, 135-140 cm. 


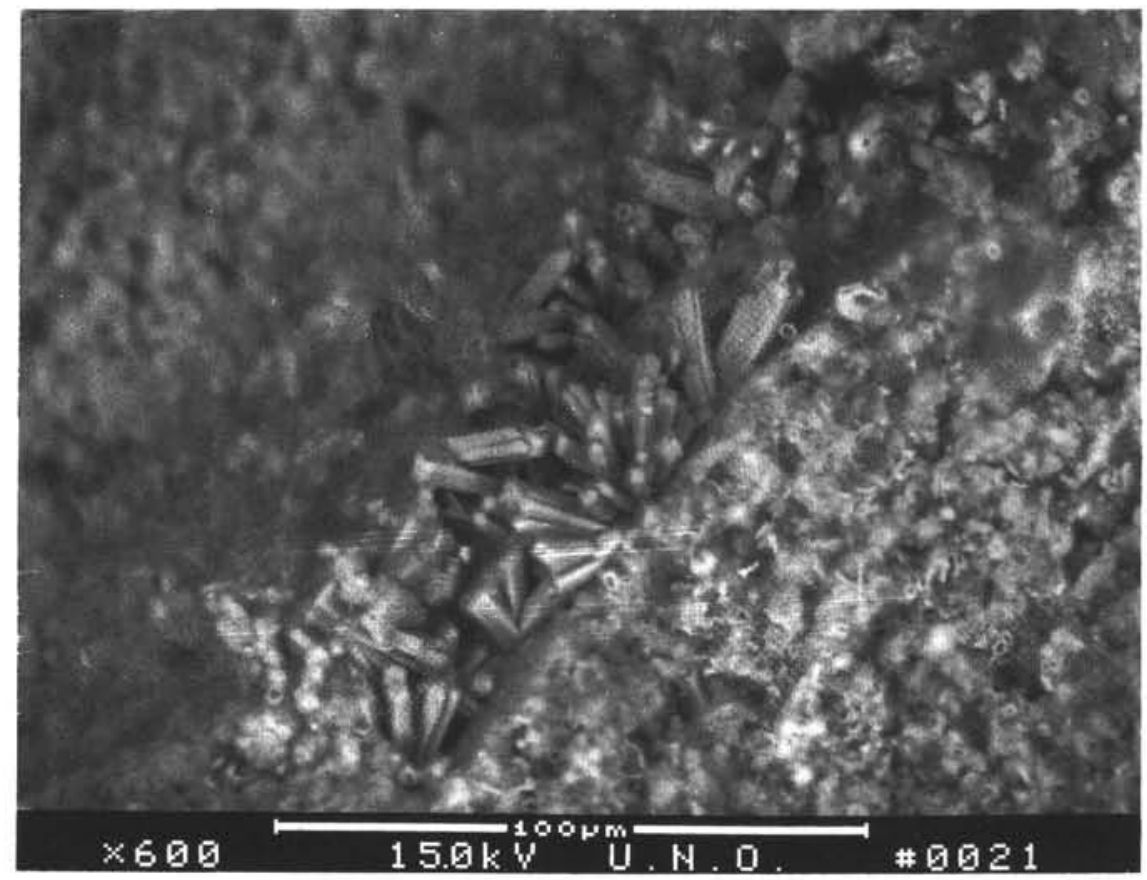

Plate 3. BSE micrograph of probable phillipsite crystal cluster from fractured subsample of Sample 135-834A-9H-4, 135-140 cm.

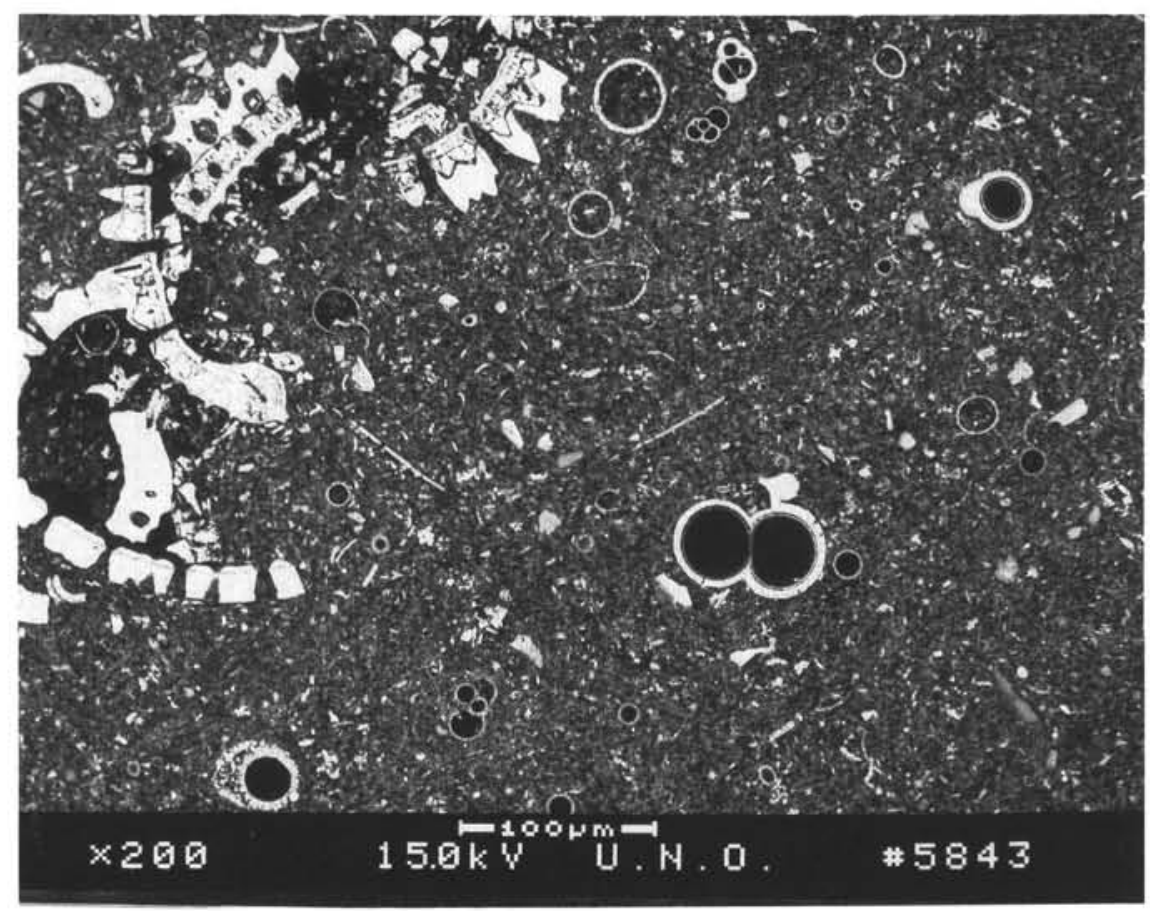

Plate 4. BSE micrograph of Sample 135-835A-8H-4, 135-140 cm. 


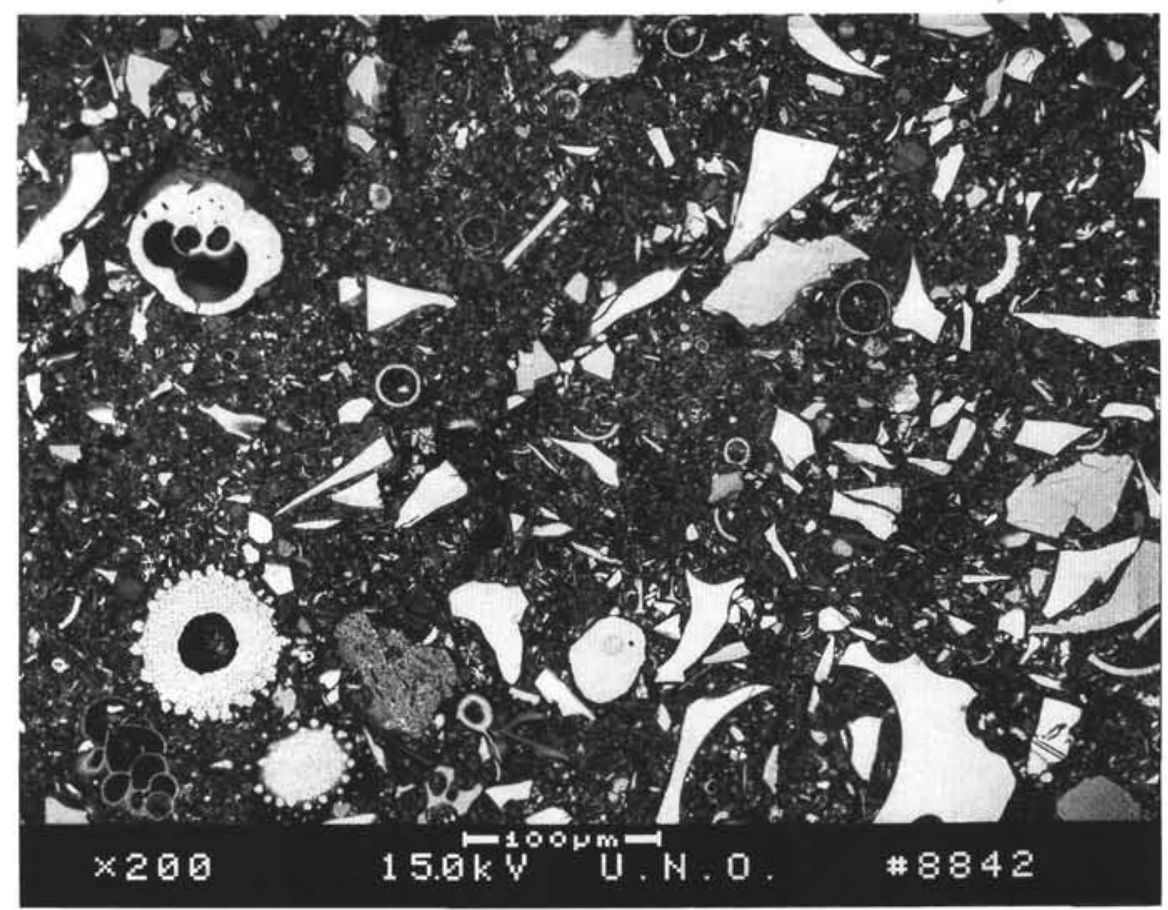

Plate 5. BSE micrograph of Sample 135-838A-8H-4, 135-140 cm.

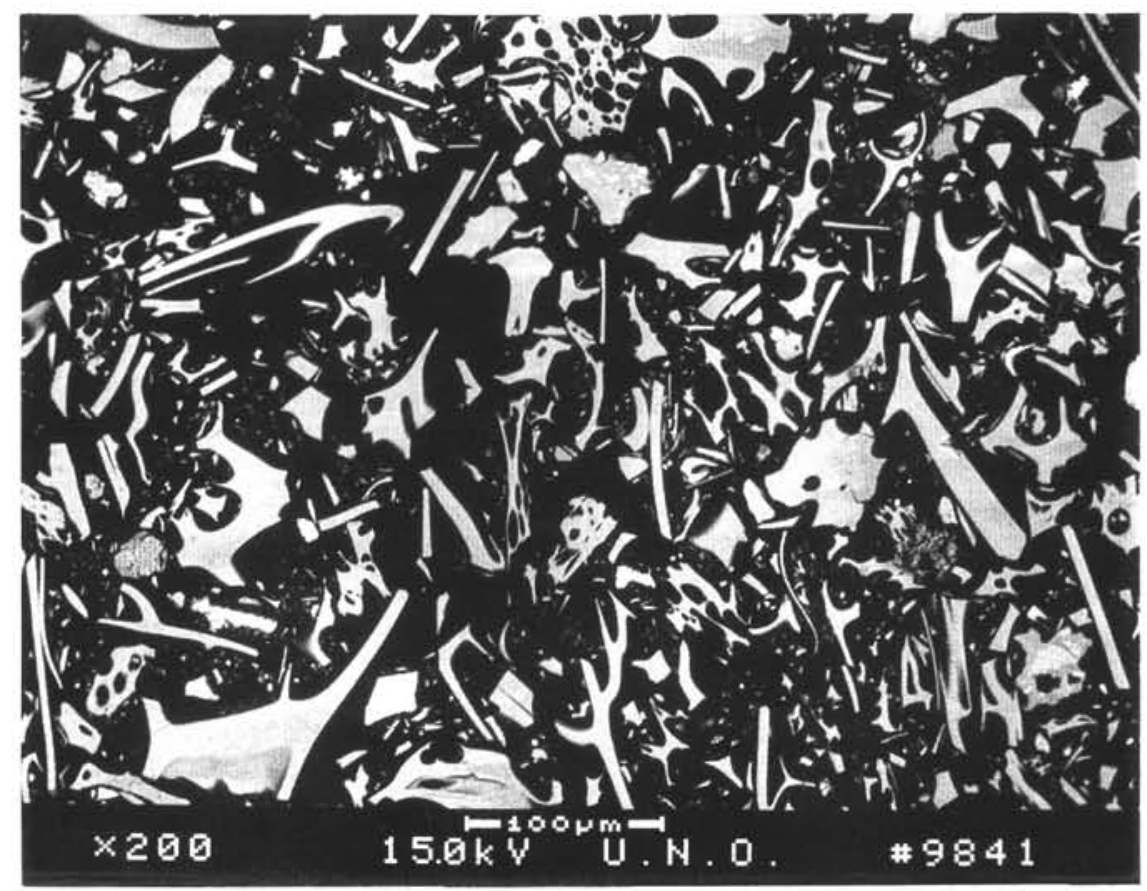

Plate 6. BSE micrograph of Sample 135-839A-8H-4, 135-140 cm. 